\title{
PERSEPSI WISATAWAN TERHADAP AKUN MEDIA SOSIAL INSTAGRAM @WATUAMBEN
}

\author{
Nuharani Erningdyah K \\ NIDN: 0530046603
}

e-mail : nuh4r4n1@yahoo.co.id
Oleh

Sekolah Tinggi Pariwisata AMPTA Yogyakarta
Dessy Rahmawati

Alumni

dsydiman12@gmail.com

\section{ABSTRACT}

Natural tourism destinations Watu Amben is tourist destinations which presents a panorama of the natural landscape which is located in the village of Pandeyan, district Piyungan, Bantul. One of the efforts made by the Manager of Watu Amben to introduce these tourist destinations to the public is using social media Instagram. Based on the foregoing, the researchers conducted a study with the title "Tourist Perception of Social Media Account Instagram@watuamben".

Research methods used in this research is qualitative research. This research was conducted in nature tourism Watu Amben, with data collection techniques observation, interview, questionnaire and the documentation. The interviews addressed to account manager Instagram @watuamben and also tourists coming to Watu Amben, while questionnaires addressed to tourists visiting the Watu Amben. The purpose of this research is to know the visitor's perception of social media account Instagram @watuamben. The result of this research is that the pictures or videos that uploaded in Instagram by @ watuamben could change the tourist perspective about tour destination waktu ambrn when they see the pictures and the videos. Also, the researchers hope that the administrators of Instagram account @ watuamben could use the media social to introduce the tour destination watu amben to publiceffectively.

Keywords: Tourists Perception, Social Media, Instagram, Watu Amben

\section{PENDAHULUAN}

Sebagai kota wisata, Yogyakarta memiliki berbagai macam wisata: alam, buatan, budaya, sejarah dan religi. Wisata alam pantai dan keindahan panorama dengan hamparan lembah, tebing dan perbukitan banyak ditemukan dan akhirnya dijadikan sebagai destinasi wisata. Terjadinya destinasi wisata baru yang secara kebetulan ini, sebagai contoh Watu Amben, karena adanya kebiasaan kalangan pelajar dan mahasiswa mengunggah hasil swafoto (selfie) dengan mengambil latar belakang keindahan panorama ke media sosial—khususnya Instagram. Perilaku wisatawan ini diharapkan dapat menjadi sarana informasi yang efektif.

Media sosial Instagram @watuamben sejauh ini menurut pengelola digunakan sebagai media untuk mengunggah keadaan di Wisata alam Watu Amben dan juga sebagai media berbagi informasi mengenai lokasi yang dapat dimanfaatkan sebagai tempat mengambil gambar untuk swafoto (selfie). Unggahan-unggahan foto dalam media sosial Intagram @watuamben ini 
diharapkan dapat mempengaruhi persepsi para pengguna Instagram. Dengan demikian ungggahan media sosial Instagram @watuamben juga dapat membentuk persepsi calon wisatawan Wisata alam Watu Amben dalam mengambil keputusan untuk berkunjung ke Wisata alam Watu Amben.

Persepsi wisatawan merupakan suatu tanggapan wisatawan terhadap suatu daya tarik wisata yang meliputi atraksi, sarana prasarana, dan aksesibilitas yang mampu menciptakan citra destinasi wisata alam Watu Amben. Berdasarkan data sementara yang diperoleh peneliti dari beberapa informan, bahwa saat ini terdapat beberapa persepsi negatif terhadap akun Instagram @watuamben antara lain yaitu terkait dengan tampilan gambar yang tidak sesuai dengan kenyataannya, kurangnya keterangan gambar yang menjadi tagar (\#) unggahan dan teknik pengambilan gambar yang kurang menarik. Namun sebagai kawasan wisata yang masih tergolong baru, saat ini akun Instagram @watuamben telah memiliki pengikut (followers) sebanyak 208 pengikut (followers), hal ini dapat dikatakan bahwa akun Instagram @watuamben memiliki jumlah yang cukup lumayan.

\section{LITERATURE REVIEW}

\section{Media Sosial}

I Gusti Ngurah Aditya Lesmana (2012) mendefinisikan media sosial sebagai sebuah kelompok aplikasi berbasis internet yang dibangun di atas dasar ideologi dan teknologi Web 2.0, dan memungkinkan penciptaan dan pertukaran user-generated content. Media sosial merupakan situs dimana setiap orang disediakan fasilitas untuk mengelola web yang sifatnya personal, kemudian terhubung dengan orang lainnya untuk berbagai informasi dan berkomunikasi. Media sosial merupakan fitur berbasis website yang dapat membentuk jaringan serta memungkinkan orang untuk berinterakasi dalam sebuah komunitas. Pada sosial media kita dapat melakukan berbagai bentuk pertukaran, kolaborasi dan saling berkenalan dalam bentuk tulisan visual maupun audiovisual. Contohnya seperti Instagram, Facebook, Blog, Path, Youtube, Google+ dan lainnya (Danis Puntoadi 2011).

Menurut Hadi Purnama (2011) media sosial mempunyai beberapa karakteristik khusus, diantaranya:

a. Jangkauan (reach): daya jangkauan social media dari skala kecil hingga khalayak global.

b. Aksesbilitas (accesibility): social media lebih mudah diakses oleh publik dengan biaya yang terjangkau.

c. Penggunaan (usuability): social media relatif mudah digunakan karena tidak memerlukan keterampilan dan penelitian khusus.

d. Aktualitas (immediacy): social media dapat memancing respon khalayak lebih cepat

e. Tetap (permanence) : social media dapat menggantikan komentar secara instan atau mudah melakukan proses pengeditan.

Media sosial mampu bersaing dengan berbagai komunikasi lainnya, bahkan memberi manfaat Danis Puntoadi (2011)

a. Personal branding is not only figure, it's for everyone: Berbagai media sosial seperti facebook, Instagram, twitter, Youtube dapat menjadi media untuk orang berkomunikasi, berdiskusi bahkan mendapatkan popularitas di sosial media. 
b. Fantastic marketing result throught social media. People don't watch TV's anymore, they watch their mobile phones: masyarakat saat ini cenderung lebih memanfaatkan telepon genggam "smartphones".

c. Media sosial memberikan kesempatan untuk berinteraksi lebih dekat dengan konsumen.Media sosial menawarkan bentuk komunikasi yang lebih individual, personal, dua arah dan melakukan interaksi secara personal serta membangun keterikatan yang lebih dalam (Danis Puntoadi, 2011).

d. Media sosial memiliki sifat viral: memiliki sifat seperti virus yaitu menyebar dengan cepat. Informasi yang muncul dari suatu produk dapat tersebar dengan cepat.

\section{Instagram}

Instagram adalah sebuah aplikasi jejaring sosial dengan berbagai foto. Penggunaan kamera melalui Instagram juga dapat langsung menggunakan efek-efek yang disediakan oleh Instagram dengan tujuan untuk mengubah foto dan video menjadi lebih menarik. Fitur-fitur Instagram menurut Siti Sulthonah (2017):

a. Pengikut (followers): pengguna Instagram yang mengikuti akun pengguna lainnya, atau memiliki pengikut Instagram. Antara sesama pengguna Instagram dapat terjalin komunikasi dengan memberi tanda suka (like) dan juga mengomentari foto atau video yang telah diunggah oleh pengguna lainnya. Followers juga dapat dikatakan satu unsur terpenting, karena jumlah tanda suka yang diberikan oleh para followers sangat mempengaruhi apakah foto tersebut dapat menjadi sebuah foto yang populer atau tidak. b. Mengunggah Foto atau Video: kegunaan utama dari Instagram adalah sebagai tempat untuk mengunggah dan berbagi foto-foto kepada pengguna lainnya.

c. Tanda Suka (Like): menjelaskan bahwa foto dan video yang telah diunggah oleh pengguna telah disukai (like) oleh pengguna lainnya. Pada fitur ini terdapat fitur Popular yaitu sebuah halaman atau kumpulan dari foto-foto popular dari seluruh dunia pada saat itu. Foto yang berada di kumpulan foto popular tersebut menjadi dikenal oleh masyarakat mancanegara sehingga dapat memungkinkan jumlah pengikut pun juga dapat bertambah lebih banyak juga.

d. Pengaturan Instagram: Instagram memiliki aturan yaitu dilarang mengunggah foto yang mengandung unsur pornografi, foto atau karya orang lain tanpa izin (plagiat). Pengguna dapat melaporkan dengan memberi tanda bendera atau flagging. Flagging (menandai foto dengan bendera) Flagging berfungsi bila pengguna merusak kerja sama dalam penggunaan Instagram karena foto yang diunggah melanggar aturan.

e. Profil Bisnis: fitur gratis untuk akun yang ingin diakui sebagai akun bisnis di Instagram. Profil yang memudahkan untuk mengakses, berkomunikasi dengan pengguna karena urusan bisnis melalui berbagai alat yang telah tersedia. Dalam profil ini terdapat Instagram Insight yaitu sebuah fitur statistik yang menampilkan siapa saja follower dari pemilik profil bisnis (demografi), kapan saja mereka online, dan lainlain 
f. Promosi: memilih postingan yang sudah dibagikan di Instagram dan menambahkan tombol yang mendorong orang untuk mengambil tindakan.

\section{Profil Akun Instagram @watuamben}

Akun Instagram Watu Amben dibuat oleh pengelola destinasi wisata alam Watu Amben dengan nama akun @watuamben. tujuan awal pembuatan Instagram @watuamben adalah sebagai media informasi dan juga alat untuk mempromosikan destinasi wisata alam Watu Amben kepada masyarakat Yogyakarta, Indonesia bahkan Dunia. Saat penelitian ini dilakukan, akun Instagram Watu Amben memiliki pengikut (followers) sebanyak 216 dan 38 unggahan foto yang digunakan sebagai media untuk memperkenalkan destinasi wisata Watu Amben. tiap unggahan foto yang ada pada akun Instagram @watuamben memiliki rata-rata 45 jumlah like atau sekitar $21 \%$ dari seluruh jumlah followers, jika dibandingkan dengan akun destinasi wisata yang serupa, seperti Tebing Breksi dengan akun Instagram @ tebing_breksi dengan jumlah pengikut 2.561, akun Instagram @tebing_breksi memiliki rata-rata 200 like, atau hanya $8 \%$ dari seluruh followers. Berikut merupakan gambar dari jumlah followers dan juga jumlah like di akunInstagram @watumben dan akun Instagram @ tebing_breksi;

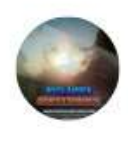

watuamben ...

Following

wa yogyakarta Kawasan tempat melihat sunset dan

keindahan alam jogja dari ketinggian, Jin patuk-dlingo km 2

Pandeyan, srimulyo, piyungan, bantul 081252708918 D7E88962
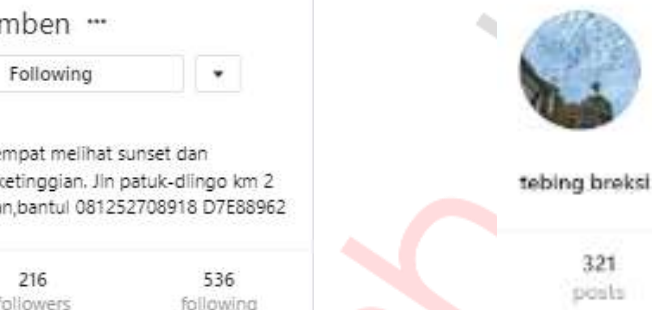

tebing_breksi ...

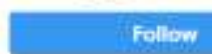

2.574

109

Gambar 1. Jumlah followers akun Instagram @watuamben dan jumlah followers akun Instagram @tebing_breksi

Sumber: Data Primer 2017
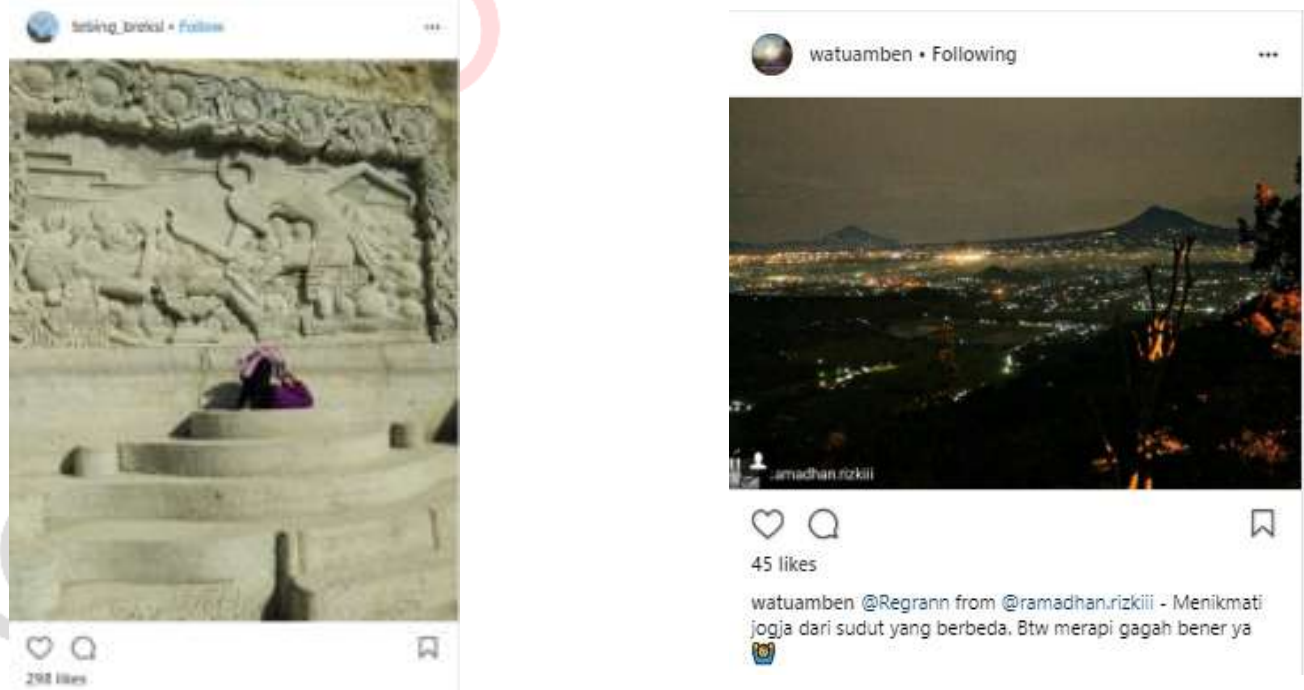

Gambar 2.Jumlah like akun Instagram @ watuamben dan jumlah like akun Instagram @ tebing_breksi

Sumber: Data Primer 2017 
Meskipun

akun Instagram@watuamben merupakan akun Instagram yang baru dan memiliki jumlah pengikut/followers yang bisa dikategorikan lumayan, namun pengelolaan akun Instagram Watu Amben oleh pihak pengelola masuk dalam kategori kurang, hal ini dapat dilihat dari beberapa unggahan-unggahan yang ada pada akun Instagram@watuamben masih monoton, dan kurang informatif, misalnya belum adanya informasi-informasi mengenai kegiatan yang akan diadakan di wisata alam Watu Amben melalui akun Instagram@watuamben.

\section{Persepsi}

\section{a. Pengertian Persepsi}

Menurut Dilla Pratiyudha Sayangbatti dan Baiquni (2013) persepsi didefinisikan sebagai sebuah proses pengorganisasian dan penginterpretasian terhadap stimulus yang diterima oleh organisme atau individu sehingga merupakan suatu yang berarti dan merupakan aktivitas yang terintegrasi dalam diri individu. Menurut Dilla Pratiyudha Sayangbatti dan Baiquni (2013) mengatakan bahwa persepsi merupakan proses yang digunakan seseorang untuk memilih, mengorganisasi, dan menginterpretasi masukan-masukan informasi guna mencip-takan gambaran dunia yang dimilikinya. Tahapan proses pembentukan persepsi: 1) Eksposur Selektif, yaitu melalui berbagai iklan yang akan disaring oleh individu berdasarkan ketertarikannya akan sesuatu. 2) Distorsi Selektif, menggambar-kan kecen-derungan orang untuk merakit informasi kedalam pengertian pribadi. 3) Ingatan/ Retensi Selektif, orang akan melupakan apa yang mereka pelajari tetapi akan mengingat apa yang mendukung sikap dan kepercayaan mereka. Dalam artian, dalam diri orang tersebut akan muncul keinginan untuk mencoba produk yang ditawarkan.

\section{b. Persepsi Konsumen}

Terbentuknya persepsi yang tepat pada konsumen menyebabkan konsumen mempunyai kesan dan memberikan penilaian yang tepat. Berdasar persepsi inilah konsumen, tertarik dan membeli. Dua produk yang mirip keadaannya dapat dipersepsikan berbeda, begitu konsumen melihat namanya berbeda. Hal ini terjadi karena proses psikologis yang kompleks yang juga melibatkan aspek psikologis. Proses psikologis penting yang terlibat dimulai dari adanya aktivitas memilih, mengorganisasi dan menginterpretasikan sehingga konsumen dapat memberikan makna atas suatu obyek.

\section{Wisatawan}

Kata wisatawan berasal dari bahasa Sansekerta "wisata" yang berarti "perjalanan" yang sama atau dapat disamakan dengan kata "travel" dalam bahasa Inggris. Menurut Koko Irawan (2010) wisatawan sama artinya dengan kata "traveler". Koko Irawan, menggunakan istilah pengunjung (visitor) untuk setiap orang yang datang ke suatu negara yang bukan tempat tinggalnya yang biasa untuk keperluan apa saja, selain melakukan perjalanan yang digaji. Dian Kusumaningrum (2009) menjelaskan bahwa wisatawan adalah orang yang sedang tidak bekerja, atau sedang berlibur dan secara sukarela mengunjungi daerah lain untuk mendapatkan sesuatu yang lain. Wisatawan terbagi dalam tiga bagian: 1) Pengunjung, setiap orang yang berhubungan ke suatu negara lain, mempunyai tempat kediaman di Negara tujuan, dengan alasan melakukan pekerjaan 
yang diberikan oleh Negara yang dikunjunginya. 2) Wisatawan adalah setiap orang yang bertempat tinggal di suatu negara tanpa memandang kewarganegaraannya, berkunjung kesuatu tempat pada Negara yang sama untuk waktu lebih dari 24 jam. 3) Darmawisata atau excursionist adalah pengunjung sementara yang menetap kurang dari 24 jam di Negara yang dikunjungi, termasuk orang yang berkeliling dengan kapal pesiar. Jadi bisa juga dikatakan wisatawan adalah seseorang yang melakukan perjalanan dari suatu tempat lain yang jauh dari rumahnya bukan dengan alasan rumah atau kantor.

\section{Destinasi Wisata}

Suatu tempat atau kawasan geografis yang berada dalam satu atau lebih wilayah administratif yang didalamnya terdapat unsur daya tarik, fasilitas, aksesibilitas serta masyarakat yang saling terkait dan melengkapi untuk mewujudkan kegiatan kepariwisataan, termasuk manajemen dan regulasinya. destinasi adalah interaksi antara berbagai elemen yang harus dikelola dengan baik. Elemen tersebut terdiri dari tiga hal yaitu wisatawan, obyek dan daya tarik wisata, serta informasi mengenai obyek dan daya tarik wisata tersebut (Dilla Pratiyudha Sayangbatti dan Baiquni 2013). Dalam sebuah destinasi, terdapat berbagai macam sub elemen yang saling mendukung dan memiliki keterkaitan satu samalain: 1) Atraksi, segala sesuatu (objek wisata) yang dapat membuat wisatawan tertarik untuk datang. 2) Kelengkapan fasilitas, segala macam fasilitas atau sarana penunjang yang dibutuhkan oleh wisatawan dalam rangka menikmati obyek dan daya tarik wisata pada suatu destinasi (objek wisata). 3) Aksesibilitas, segala bentuk sarana transportasi baik modal transportasi maupun infrastruktur penunjangnya yang menjamin kemudahan wisatawan untuk menjangkau obyek wisata. Menurut Ariyanto (dalam Liseu Lestari, 2016), ada berbagai faktor yang menentukan seseorang untuk membeli jasa atau mengunjungi destinasi wisata yaitu : lokasi, fasilitas, citra, harga / tarif dan pelayanan. Menurut Mill dan Morrison (dalam Liseu Lestari, 2016), ada beberapa variabel sosio ekonomi yang mempengaruhi permintaan pariwisata, yaitu: 1) Umur, Hubungan antara pariwisata dan umur mempunyai dua komponen, yaitu besarnya waktu luang dan aktivitas yang berhubungan dengan tingkatan umur tersebut. Terdapat beberapa perbedaan pola konsumsi antara kelompok yang lebih tua dengan kelompok muda. 2) Pendapatan, sebagai pertimbangan untuk biaya pengeluaran yang akan digunakan untuk semua aktivitas yang dilakukan selama mengadakan perjalanan. 3) Jenis Kelamin, ada kecenderungan perempuan lebih banyak melakukan kegiatan budaya (cultural activities), sedangkan laki-laki lebih menyukai rekreasi ditempat terbuka (outdoor recreation) atau olahraga. 4) Pendidikan, mempengaruhi tipe dari waktu luang yang digunakan dalam perjalanan yang dipilih, memotivasi untuk melakukan perjalanan wisata, atau mempengaruhi pandangan seseorang dan memberikan lebih banyak pilihan yang dapat diambil seseorang.

\section{Pariwisata}

Menurut Soebagyo (2012) pariwisata adalah "perkawasanan dari suatu tempat ke tempat lain, bersifat sementara, dilakukan perorangan maupun kelompok, sebagai usaha mencari keseimbangan atau keserasian dan kebahagiaan dengan lingkungan hidup dalam dimensi sosial, 
budaya, alam dan ilmu". Murphy dalam I Gde Pitana dan Gayatri (2005), berpendapat bahwa pariwisata adalah keseluruhan elemen-elemen terkait (wisatawan, daerah tujuan wisata, perjalanan, industri dan lainlain) yang merupakan akibat dari perjalanan wisata ke daerah tujuan wisata, sepanjang perjalanan tersebut tidak permanen. Dalam Undang-undang Nomor 10 tahun 2009, disebutkan pariwisata adalah segala sesuatu yang berhubungan dengan wisata, termasuk pengusahaan obyek dan daya tarik wisata serta usaha-usaha yang berhubungan dengan penyelenggaraan pariwisata.

\section{METODE PENELITIAN}

Penelitian ini merupakan penelitian deskriptif kualitatif yang bertujuan untuk memahami fenomena sosial yang menitikberatkan pada suatu deskripsi tentang fenomena yang dikaji yaitu presepsi wisatawan Wisata alam Watu Amben terhadap media sosial Instagram Wisata alam Watu Amben. Pengumpulan data primer dilakukan dengan metode in-depth interview, observasi lapangan dan kuesioner. Pengumpulan data sekunder diperoleh dari studi kepustakaan. Keabsahan data diuji dengan triangulasi yaitu kroscek tiga data dan tiga sumber. Sedangkan dalam analisis data melalui reduksi, penyajian data, dan verifikasi

\section{HASIL PENELITIAN DAN \\ PEMBAHASAN \\ HASIL PENELITIAN}

\section{Hasil Kuesioner}

Dari karakteristiknya usia wisatawan yang paling banyak berkunjung ke wisata alam Watu Amben didominasi oleh usia 2130 tahun sebanyak 17 orang atau 57\% responden. Mayoritas dari wisatawan berjenis kelamin laki-laki dengan perbandingan $60 \%: 40 \%$ perempuan. Ditinjau dari sisi pendidikan, SMA/Sederajat $37 \%$ merupakan persentase tertinggi wisatawan yang berkunjung ke Watu Amben. Wisatawan Watu Amben $33 \%$ adalah pelajar/mahasiswa yang orang tuanya $33 \%$ berpenghasilan 2 juta-4 juta atau dapat dikatakan berasal dari golongan ekonomi menengah ke atas dan bertempat tinggal/domisili di Yogyakarta $77 \%$ atau 23 orang dari 30 responden.

Dilihat dari medianya yaitu Instagram diperoleh data bahwa $53 \%$ wisatawan setuju kalau unggahan akun Instagram @watuamben menarik. Hal ini dikuatkan dengan $50 \%$ responden tertarik memfollow setelah melihat unggahan akun Instagram @watuamben. 43\% wisatawan menyatakan akan memfollow akun Instagram @watuamben karena ingin mendapatkan informasi. Wisatawan yang menjadi responden $47 \%$ menyatakan bahwa mereka menyarankan ke teman/keluarga untuk memfollow akun Instagram @watuamben. Setelah melihat unggahan foto-foto di akun Instagram@watuamben, $30 \%$ responden menyatakan akan berkunjung ke Watu Amben

\section{Hasil wawancara}

Wawancara dilaksanakan dengan narasumber pengelola objek wisata Watu Amben yang juga merangakap sebagai Ketua RT 4 dusun Pandeyan lokasi Watu Amben berada. Dari wawancara diketahui bahwa akun@watuamben belum dikelola secara profesional karena pengelolaan dilakukan ketika waktu senggang di malam hari saja. Akun Instagram@watuamben dibuat untuk mengenalkan dan menunjukkan keberadaan wisata alam Watu Amben. Dalam melakukan unggahan, pengelola akun tidak banyak melakukan pertimbangan akan foto-fotonya asalkan 
menyajikan pemandaangan kawasan Watu Amben dan sekitarnya. Akan tetapi ketika pada akhirnya pengelola mengetahui bahwa media Instagram memilik peran penting atas kunjungan wisatan ke Watu Amben, maka pengelola bersama dengan pokdarwis melakukan pembagian tugas menjaga dan memelihara wisata alam Watu Amben.

Peneliti juga melakukan wawancara kepada wisatawan yang berkunjung ke Watu Amben dan aktif menggunakan Instagram. Wisatawan menyatakan Instagram merupakan media sosial yang sangat berpengaruh dalam menarik kunjungan ke suatu destinasi wisata, apalagi foto-foto yang diunggah sesuai dengan keadaan yang ada di objek wisata, serta menarik. Bagi wisatawan yang diwawancarai berkunjung ke destinasi wisata alam merupakan kebutuhan untuk refreshing dan juga sebagai referensi tempat pengambilan foto. Menurut wisatawan yang diwawancarai beberapa foto yang diunggah kurang menarik atau bahkan kurang tepat untuk diunggah di akun Instagram @watuamben. Pengguna Instagram juga ingin mendapatkan informasi tentang event yang akan diadakan, harga makanan serta cuaca dan informasi lain yang mungkin diperlukan.

\section{PEMBAHASAN}

Wisata alam Watu Amben yang tergolong destinasi baru lebih banyak dikunjungi oleh kaum adam (laki-laki). Hal ini kemungkinan dikarenakan hobi lelaki yang menyukai petualangan outdoor. hal ini didukung oleh teori yang dikemukakan Mill dan Morrison (dalam Liseu Lestari, 2016) bahwa laki-laki lebih menyukai rekreasi ditempat terbuka (outdoor recreation) atau olahraga.
Wisatawan wisata alam Watu Amben yang didominasi dengan usia 21 hingga 30 tahun, maka pembuatan akun media sosial Instagram yang dilakukan oleh pengelola wisata alam Watu Amben dengan username @watuamben merupakan langkah yang tepat. Hal ini sesuai dengan data yang ada pada gambar 3, yang menunjukkan bahwa pengguna media sosial Instagram di Indonesia dengan usia 16-35 tahun melebihi angka 50\% dan lebih dominan dibanding media sosial lainnya,

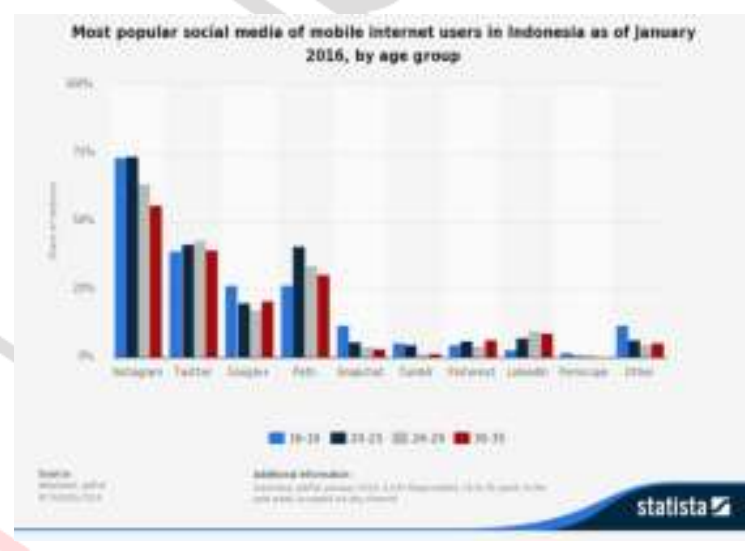

Gambar 3 Tabel Media Sosial Terpopuler di IndonesiaJanuari Tahun 2016 Sumber :statista.com

Hasil wawancara dengan wisatawan menggambarkan bahwa wisatawan mengenal destinasi Watu Amben dari unggahan foto-fotonya. Untuk itu penggunaan Instagram yang dilakukan pengelola sudah tepat. Pengelola menggunakan Instagram sebagai media untuk menyebarkan informasi dan mempublikasikan tentang wisata alam Watu Amben dan sekitarnya. Seperti yang dikemukakan oleh Danis Puntoadi (2011) bahwa berbagai media sosial...dapat menjadi media untuk orang berkomunikasi, berdiskusi bahkan mendapatkan popularitas... meskipun popularitas Watu 
Amben masih terbatas di kalangan wisatawan Yogyakarta.

Informasi berupa foto yang disampaikan akun Instagram@watuamben dapat membentuk persepsi para pengguna Instagram yang tidak lain merupakan calon wisatawan, untuk mengambil keputusan berkunjung ke Watu Amben. Keterangan ini didukung dengan hasil wawancara dengan wisatawan yang datang ke Watu Amben bahwa unggahan-unggahan yang berhu-bungan dengan wisata alam Watu Amben bisa membuat calon wisatawan berkunjung ke wisata alam Watu Amben, pernyataan di atas juga berbanding lurus dengan pernyataan Hadi Purnama (2011) bahwa sosial media dapat memancing respon khalayak lebih cepat. Melalui media sosial yang memiliki sifat viral menjadikan informasi cepat tersebar bagai virus (Danis Puntoadi, 2011). Setelah menerima stimulus informasi berupa foto-foto, kemudian diinterpretasikan sehingga mengubah persepsi dan akhirnya calon wisatawan memutuskan berkunjung karena terciptanya gambaran akan dunia yang dimilikinya (Dilla Pratiyudha Sayangbati \& Baiquni, 2013). Sedangkan Oka A Yoeti (2008) mengatakan bahwa wisatawan memiliki kesan dan impian tersendiri tentang daerah tujuan wisata yang akan dikunjungi. Oleh karenanya media social menurut Danis Puntoadi (2011) mempunyai manfaat sebagai pemasaran yang fantastis.

\section{KESIMPULAN DAN REKOMENDASI KESIMPULAN}

Media merupakan sarana komunikasi yang sangat membantu untuk penyebaran bermacam-macam informasi, gambar/foto, video atau pun informasi tertulis lainnya. Di era milineum ini informasi visual lebih digandrungi dari yang lainnya. Respon pengguna media sosial, khususnya Instagram cenderung lebih memperhatikan gambar atau video, sehingga mengenalkan destinasi wisata baru sangat dipermudah. Kecepatan informasi ke pengguna Instagram mengarus-kan pengelola standby dengan mengunggah informasi terbaru. Namun ketidaktelitian pengguna media sosial akan menjerumuskan ke informasi yang tidak benar, bohong atau hoax yang sangat merugikan.

\section{REKOMENDASI}

Pengelola sebaiknya selalu standby untuk mengunggah informasi terbaru atau dengan kata lain pengelola selalu meng-up date unggahan-unggahannya, agar pengguna mendapatkan informasi yang selalu baru dan yang paling penting adalah untuk membuat pengguna media sosial tertarik dan akhirnya memutuskan untuk berkunjung.

\section{REFERENSI}

Danis Puntoadi. 2011. Menciptakan Penjualan Melalui Social Media. Jakarta : PT Elex Komputindo.

Dian Kusumaningrum. 2009. Persepsi Wisatawan Nusantara Terhadap Daya Tarik Wisata Di Kota Palembang: Tesis. Tidak dipublikasikan. Yogyakarta: Sekolah Pascasarjana UGM.

Dilla Pratiyudha Sayangbatti dan Baiquni, M. 2013. Motivasi dan Persepsi Wisatawan Tentang Daya Tarik Destinasi Terhadap Minat Kunjungan Kembali di Kota Wisata Batu.Jurnal Nasional Pariwisata, Vol. 5, No. 2 pp 126-136.

Hadi Purnama. 2011. Media Sosial di Era

Pemasaran 3.0 Corporate and Marketing Communication: Tesis. 
Tidak dipublikasikan. Jakarta: Pusat

Studi Komunikasi dan Bisnis

Program Pasca Sarjana Universitas

Mercu Buana.

I Gde Pitana \& Putu G. Gayatri. 2005.

Sosiologi Pariwisata. Yogyakarta : Andi Offset.

I Gusti Ngurah Aditya Lesmana, 2012. Analisis Pengaruh Media Sosial Twitter terhadap Pembentukan Brand Atachment (Studi : PT XL Axiata): $\quad$ Skripsi.Tidak dipublikasikan. Jakarta: Fakultas Ekonomi Universitas Indonesia.

Koko Irawan. 2010. Potensi Objek Wisata Air Terjun Serdang Sebagai Daya Tarik Wisata Di Kabupaten Labuhan Batu Utara: Skripsi.Tidak dipublikasikan. Sumatera Utara: Program Pendidikan Non Gelar Pariwisata Universitas Sumatera

Liseu Lestari. 2016. Faktor-Faktor yang Mempengaruhi Frekuensi Kunjungan Wisatawan ke Objek Wisata Istana Maimun Medan. Bandung. Skripsi. Tidak dipublikasikan. Program Studi Pembangungan, Fakultas Ekonomi, Universitas Pasundan

Siti Sultonah. 2017. Pemanfaatan Instagram Dalam Promosi Perpustakaan: Studi Kasus Simpul Library-Pustakalana di Bandung: Skripsi. Tidak dipublikaskan. Jakarta: Program Studi Ilmu Perpustakaan, Fakultas Adab dan Humaniora, Universitas Islam Negeri Syarif Hidayatullah.

Soebagyo. 2012. Strategi Pengembangan Pariwisata di Indonesia. Jurnal Liquidity, Vol. 1, No. 2, pp 153-158 